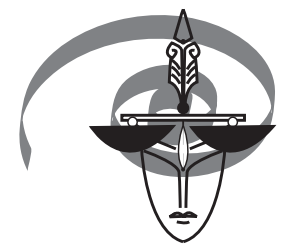

\title{
EUROPEAN
}

Volume $8 \cdot 2014 \cdot$ Number $2(28)$

DOI: 10.2478/ep-2014-0005

Jan Widacki

Andrzej Frycz Modrzewski Krakow University.

Krakow

Poland

\section{Results of Polygraph Examinations: Direct or Circumstantial Evidence?}

Key Words: polygraph in court, evidence, polygraph as evidence

The division of evidence into bezpośrednie (direct) and pośrednie (circumstantial) is commonly used in the Polish doctrine (Cieślak 1955, Gaberle 2007, J. Nelken 1970). In both languages, "circumstantial evidence" stands in opposition to "direct evidence" (Ingram 2012, Inman, Rudin: 2001, Roberts, Redmayne 2001, Kiely 2001).

Let's imagine a following case: $\mathrm{X}$ has admitted to murdering A. Witness $\mathrm{Y}$ testified that he saw X killing A. Trace of A's DNA was discovered on the clothing of X.

The case is relatively simple. The court has three pieces of evidence to evaluate:

\footnotetext{
"jan.widacki@gmail.com
} 
1) admission of suspect $X$ (true or false)

2) testimony of witness $Y$ (true or false)

3) result of laboratory analysis (practically certain, if certain conditions have been met).

The first two pieces of evidence refer directly to the main fact. They are direct evidence. The third piece does not refer directly to the main fact; it belongs among circumstantial evidence.

The logical analysis of the first two pieces of evidence is as follows:

if $\mathrm{X}$ tells the truth, A killed $\mathrm{X}$

if $\mathrm{Y}$ tells the truth, A killed $\mathrm{X}$.

The same analysis conducted for the third piece is as follows: if the DNA examination was conducted correctly, then traces of victim A's DNA are found on the clothing of X.

Let's assume for a while that the court has at its disposal not only a method of assessing the veracity of testimony and explanation but also a method for evaluating the correctness of performing DNA tests.

The recognition of the statements made by suspect $X$ (admission) and witness $\mathrm{Y}$ as true implies that suspect $\mathrm{X}$ actually killed victim $\mathrm{A}$.

Recognising the sentence "there is DNA trace coming from the victim A on the clothing of suspect X" as true does not in turn result in the implication that the suspect X killed victim A. The only implication is that victim A had contact with the clothing of $\mathrm{X}$. What is therefore known is the consequence of a fact. What could that fact be? Possibly, X actually killed A, and therefore $\mathrm{X}$ (his clothing) had contact with A, yet theoretically X could also have contact with $\mathrm{A}$ in circumstances other than murder. Even more, it might have been not X himself but his clothing that had contact with A (somebody might have put on X's clothing, or make it touch A's body in any other manner).

Whichever is true, what we're dealing here with is a situation in which we infer the reason (cause) from consequences, which is reductive inference, i.e. uncertain by its very assumption, and follows the pattern of "if $p$ then $q$ and q, and therefore p" (Ziembiński 1984).

The main fact of interest for the court could have been the precedent of the known consequence, determined through the DNA test. But it did not have 
to. In the case of direct evidence, the court must limit itself to the evaluation of veracity of the admission or testimony. Once it recognises truthfulness, the main fact has been proved.

When dealing with circumstantial evidence, besides the assessment of veracity (validity) of the outcome (in this case: DNA test results), the court has to assume the following way of reasoning: first answer if the determined fact is a result (consequence) of the main fact, and then evaluate whether the hypothesis that it is such a consequence is actually the most convincing one.

Let's now assume that in the case of the murder of A, the court has the following evidence at its disposal:

1) witness $Z$ testified that he saw suspect $X$ killing $A$

2) suspect $X$ does not admit to the killing

3) trace of victim A's DNA was discovered on the clothing of suspect $X$

4) a polygraph examination of suspect $X$, performed in CQ technique, showed that $\mathrm{X}$ reacted to the critical questions in the tests in the way that is usual for people who answer such questions deceptively, which means that they lie or withhold the fact of having certain information related to the killing.

Now, the court has the following evidence to evaluate:

1) testimony of witnesses $Z$ (false or true)

2) non-admission of suspect $X$ (true or false)

3) result of DNA test results (practically certain, if certain conditions have been met)

4) result of polygraph examination (to what degree certain?).

The first two belong to direct evidence, and in their case it is enough to evaluate their validity. The third piece belongs to circumstantial evidence, which means that not only its validity must be verified, but it also needs reductive inference whether the proved fact is a result of the main fact. How to treat the result of polygraph examination? Does it belong to direct or circumstantial evidence?

If the results of polygraph examination were as certain as DNA test results, the result of the expertise (which a polygraph examination performed by an expert witness is) would have to be considered direct evidence, in the same way as testimony of an eyewitness is, additionally meeting the criterion of certainty of circumstantial evidence. If this were the case, practically all other evidence would have been redundant. The entire evaluation of evidence could be limited to conducting a polygraph examination, and making it the foundation of the sentence. 
One could expect that the resistance of trialist lawyers against admitting a proof from polygraph examinations resulted mostly from this reason: the fear that a polygraph examination will dominate the evidential process in criminal trials.

In its sentence of 8th July 1980 (II KR 211/80, OSPiKA 1981, 1, item 15) the Supreme Court recognised polygraph examination, although admissible, "not at all necessary, especially for evidential purposes, and therefore for the ascertainment of a specific fact, i.e. a part of the so-called factual circumstances, as it serves only the disclosure of emotional reactions of the organism of the subject in the course of the examination itself". This shows that the Supreme Court recognised polygraph examinations admissible in the trial, yet as circumstantial evidence. It is not, however, admissible as direct evidence, serving the ascertainment of "a specific fact".

In turn, 13 years later, the Appellate Court in Poznan included the following in its sentence of 2nd December 1993 (II Akr 268/93, OSA 1994/5/31): "without entering theoretical considerations concerning the power of evidence of the results of a variograph [i.e. polygraph] examination in a criminal trial, the court believes that it must be stated that subjection of the accused to a variograph examination (as it was formulated in the defender's motion - "for the verification of his explanation" - is inadmissible, if - following the content of art. $4 \mathbb{\$} 1$ of [the Polish] Criminal Procedure Code, which guarantees free evaluation of evidence to the court - judges rule on the grounds of the evidence proving the existence of specific facts that at the same time allow the inference of the court's internal opinion about the guilt or innocence of the defendant. Being an act of intellect and will, this opinion of the judges inferred from evidence in the course of their free evaluation, cannot be constrained or restricted with results of specific examinations that would limit the free evaluation of evidence."

The position of the court is unambiguous here. A situation where a polygraph examination would be there to verify the explanations of the defendant, being direct evidence by its very nature, is inadmissible. For in this way, it would not only become direct evidence, but such a form of direct evidence whose value is a priori defined, and on the one hand is not a subject of evaluation of the court, and release the court from the evaluation of another piece of evidence on the other.

It is worth noting that most Polish course books in criminal and forensic studies place polygraph (usually referred to as variograph) examinations, as 
if disrespectful for this position, in the chapters devoted to interrogation, and present such examinations as methods for verification of statements and explanations.

For understandable reasons, the more the partisans of polygraph examinations will continue to prove their infallibility, the stronger the resistance of lawyers against the admission of such a proof will grow. It will be so as it will be perceived as direct evidence, with a priori defined value, that does not yield to the evaluation of the court, as it releases the court from the evaluation of the testimony or explanation.

It is a lucky paradox that the diagnostic value of a polygraph examination, although far from $100 \%$, is comparable with the diagnostic value of other methods of identification used in criminal procedures (Widacki 1977, Widacki, Horvath 1978).

The diagnostic value of a polygraph study, calculated or estimated for various examination techniques, is set by various authors in the range of $80 \%-95 \%$ of correct results (Abrams 1973, APA Report 2011).

The conclusion of the opinion from polygraph examination made in the control questions technique contains the following expression: "the examinee reacted to the question in the test in the way that is usual for people who answer these questions deceptively, that is they either consciously lie or withhold the fact of having information they are asked to provide in the examination". How, then, should one understand the word "usual"? A reference must be made here to the diagnostic value of polygraph examination. In this case, "usual" means that any number in the range from $80 \%$ to $95 \%$ of liars undergoing the examination would react in the same way as the subject of the test. Or in other words, only from $5 \%$ to $20 \%$ of truthful subjects would react to test questions in the way the subject did. This means that what the court receives from the expert is following information: "some subjects react like liars even when they provide true answers to test questions. There are from 5 to 20 of such people in each one hundred subjects."

Whether this individual subject belongs to the majority reacting in a typical manner or to the minority whose reactions are not typical remains unknown. Which is the case only a court can decide, evaluating the result of the polygraph examination in the context of other evidence, already evaluated.

The evaluation of evidence from polygraph examination is performed precisely like the evaluation of any circumstantial evidence. The court must 
evaluate whether the result of the examination stems from the fact that the subject actually and consciously lied or withheld information he was asked about, or whether he reacted in this way for other reasons. Thus, what we are dealing here with also here, much like in the case of evaluation of all indirect evidence, is reductive inference, which means using a known consequence (reaction to critical questions) to draw conclusions that refer to an uncertain (as it is one of the possible) reason (cause).

Thus, what a polygraph examination, in its capacity of an examination performed by an expert witness as part of his expertise, provides is circumstantial and not direct evidence.

\section{References}

Abrams S., Polygraph validity and reliability: a review, Journal of Forensic Sciences, 1973, 18, 4, pp. 313-326.

Cieślak M., zagadnienia dowodowe w procesie karnym, t. I Wyd. Prawnicze, Warszawa 1955, p. 82 and ff.

Gaberle A., Dowody w sądowym procesie karnym, Oficyna a Wolters Kluwer business, Kraków 2007, p. 44 and ff.

Inman K., Rudin N., Principles and practice of criminalistics. The profession of forensic science, CRC Press, Boca Raton, London, New York, Washington D.C., 2001, pp. 101-102. 110, 158.

Ingram J.L., Criminal evidence, Elsevier, Amsterdam, Boston, Heidelberg, London, New York, Oxford, Paris, San Diego, San Francisco, Singapore, Sydney, Tokyo 2012, pp. 98-104.

Innovations in evidence and proof. Integrating theory, research and teaching, P.Roberts, M. Redmayne (eds.), Hart Publishing, Oxford and Portland, 2009, pp. 219 and ff.

Kiely T. F., Forensic evidence: science and the criminal law, CRC Press, Boca Raton, London, New York, Washington D.C. 2001, pp. 38-39, 169, 173, 277.

Nelken J., Dowód poszlakowy w procesie karnym, Wydawnictwo Prawnicze, Warszawa 1970, pp. 89 and ff.

Report APA, Polygraph, special issue, 2011. 
Widacki J., Wartość diagnostyczna badania poligraficznego i jej znaczenie kryminalistyczne, Wyd. UJ, Kraków 1977.

Widacki J., Horvath F., An experimental investigation of the relative validity and utility of the polygraph technique and three other common methods of criminal identification, Journal of Forensic Sciences, 1978, 23,3, pp. 596601.

Ziembiński Z. Logika praktyczna , PWN Warszawa 1984, pp. 170-173. 